\title{
Thermal Properties of Beef Tallow/Coconut Oil Bio PCM Using T-History Method for Wall Building Applications
}

\author{
Razali Thaib, Muhammad Amin, and Hamdani Umar
}

\begin{abstract}
Thermal energy storage using Phase Change Materials (PCM) is now widely applied to wall buildings. In general, PCM which is used for applications on building walls is organic $\mathrm{PCM}$ and has temperature range from $0^{\circ} \mathrm{C}$ to $65^{\circ} \mathrm{C}$. Beef tallow and coconut oil is a type of organic PCM known as Bio PCM needs to characterize by using the T-History Method. The T-History method is more accurate than Differential Scanning Calorimetry (DSC) and Differential Thermal Analysis (DTA). This study aimed to determine the thermal properties of beef tallow/coconut oil PCM using the T-History method. The beef tallow and coconut oil as bio PCM material was used in this study with the variation are respectively: $100 \%, 70+30 \%, 60+40 \%$, and $50+50 \%$. Tests are carried out using the T-History method. From the results of testing and analysis obtained supercooling temperature, melting temperature, specific heat, and latent heat for bio PCM beef tallow/coconut oil. The effect of adding coconut oil mixture to beef tallow caused a decrease in melting temperature and supercooling temperature, while the specific heat and latent heat of bio PCM of beef tallow/coconut oil ranged from 2.96$2.19 \mathrm{~kJ} / \mathrm{kg}$. ${ }^{\circ} \mathrm{C}$ and $101.05-72.32 \mathrm{~kJ} / \mathrm{kg}$. The result obtained that this bio PCM material of cow beef tallow/coconut oil can apply, as additional material in wall building application.
\end{abstract}

Index Terms-Phase Change Material, Coconut Oil, Beef Tallow, T-History.

\section{INTRODUCTION}

We always feel uncomfortable conditions in the room if it is in the summer. One of the inconvenience factors is because the walls of a building that is designed cannot withstand heat from outside the walls of the building are designed mostly from concrete which has high heat conductivity [1]. One effort to overcome these problems is to manipulate these concretes by adding a Phase Change Material (PCM) which can withstand the heat. So that the heat in the room is maintained [2].

PCM is a material that has latent heat that can store large amounts of heat energy at constant temperatures [3], [4]. PCM consists of organic, inorganic and eutectic which have their respective thermal properties [5]. Therefore, it is necessary to choose PCM that is appropriate for its thermal properties. So that the thermal properties can also be applied to the walls of the building.

Published on November 19, 2019

R. Thaib is with the Mechanical Engineering Department, Engineering Faculty, Universitas Syiah Kuala, Banda Aceh, Indonesia. (e-mail: razalithaib@unsyiah.ac.id).

M. Amin was with the Mechanical Engineering Department, Engineering Faculty, Universitas Samudra, Kota Langsa, Indonesia. (email: rmuhammadamin@unsam.ac.id).

H. Umar is with the Mechanical Engineering Department, Engineering Faculty, Universitas Syiah Kuala, Banda Aceh, Indonesia. (e-mail: hamdani@unsyiah.ac.id).
PCM most easily obtained by the PCM organic and has many advantages compared to inorganic and eutectic PCM. Organic PCM can be obtained from various material sources such as vegetation, animals, and petroleum or minerals [6], [7]. One example of plants is coconut oil [8] whereas from animals, namely beef tallow [9], where both types have material properties capable of changing phase from solid to liquid or vice versa. Both types of material are named bio PCM due to their source from nature.

There are several ways to obtain thermal properties, namely by using a Differential Scanning Calorimetry (DSC) measuring instrument [10], Differential Thermal Analysis (DTA) [11] and using the T-History method [12]. The DSC and DTA measuring instruments have the advantage that the data can be directly analyzed [13]. While the drawback is that the gauge is expensive and the sample used is tiny in size, where for DTA the sample size is usually 10 to $150 \mathrm{mg}$ while for DSC the sample size is usually 1 to $50 \mathrm{mg}$ [14]. This size causes the thermal properties of PCM not to be representative for applications that use large samples. Also, data collection cannot be carried out for the same sample, where DTA and DSC measuring instruments are usually carried out for one data sample. While the T-History method has the advantage that the rate of heating/cooling is slow so that the freezing point and melting point of PCM are obtained more accurately. Besides, it is easy to observe supercooling because the PCM sample used has a large volume.

Based on the above study, this study will examine the thermal properties of beef tallow/coconut oil bio PCM using the T-History method. The hope is that bio PCM can be used as heat storage on building walls.

The purpose of this study was to determine the thermal properties of beef tallow/coconut oil bio PCM. Where the thermal properties are melting temperature, latent heat, and heat capacity, this data can be used as a recommendation material in designing building walls that have heat-resistant materials.

\section{MATERIALS AND METHOD}

\section{A. Materials}

PCM used in this study was beef tallow and coconut oil. The process of making beef tallow starts with buying beef tallow from the market and then separating between fat and meat. They are then boiled at a temperature of $100{ }^{\circ} \mathrm{C}$ until the water boils. The beef tallow from the boiling process is then reheated (without water) into the container at a temperature of $200{ }^{\circ} \mathrm{C}$ until the oil comes out, then the oil is filtered and done the drying process finally. From the results of the drying, the beef tallow PCM was obtained. 
The process of making coconut oil is the first coconut core separated from the coconut shell and then dried for 24 hours. Then shredded and mixed with water to squeeze to produce coconut milk, then left until the water and oil separate. The oil is taken and cooled until frozen, and the result is PCM coconut oil.

This coconut oil is mixed with beef fat with variations of 30, 40 and $50 \%$ respectively. Then tested the thermal properties using the T-history method.

\section{B. Method}

This research is an experimental study using the $\mathrm{T}$ History method, and from experimental results, it is then analyzed based on the Yinping equation [15]. PCM of beef tallow and coconut oil varied by $100 \%, 70+30 \%, 60+$ $40 \%$, and $50+50 \%$ respectively. The data to be obtained are the thermal properties of PCM such as melting temperature $\left({ }^{\circ} \mathrm{C}\right)$, heat capacity $\left(\mathrm{kJ} / \mathrm{kg} .{ }^{\circ} \mathrm{C}\right)$, and latent heat $(\mathrm{kJ} / \mathrm{kg})$.

Before testing using the T-History method, the PCM thawing process and heating water (reference). Two tubes consisting of the first tube containing water as a reference and another tube filled with PCM samples. The mass of the two tubes (tube) is known to be 80 gr each while the mass of water and PCM are $93 \mathrm{gr}$ and 90 gr respectively. A hot water container is used to melt PCM and to heat water (reference). When PCM is ascertained all have melted (heated above the melting point of PCM) and the temperature of the water (reference) is the same as the PCM temperature, then the two tubes are transferred to the environment for the natural freezing/cooling. When PCM and water (reference) are frozen/cooled, the temperature will drop until it is completely constant. When it is confirmed that the test is constantly stopped.

To find out the phenomena that occur in the sample ktype thermocouples are installed with a diameter of $0.3 \mathrm{~mm}$. The thermocouple is connected to the Agilent 34970 A type of acquisition data. Data obtained from reading Agilent $34970 \mathrm{~A}$ is recorded and stored on a computer device as shown in Figure 1. Data from this computer will then be processed into a T-History graph. This T-History graph is then analyzed using the equation quoted from the Yinping reference [15].

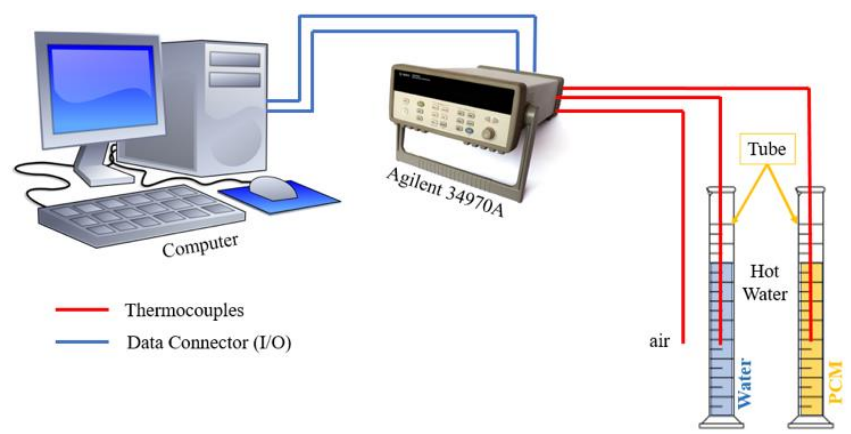

Fig. 1. The process of measuring beef tallow/coconut oil bio PCM using the T-History method

\section{RESUlts AND DisCUSSIONS}

Testing of thermal properties using the T-History method has been successfully carried out as evidenced by the emergence of supercooling on the temperature profile. Figure 2 is a temperature to time profile with a $100 \%$ sample beef tallow, beef tallow + coconut oil $70+30 \%$, beef tallow + coconut oil $60+40 \%$, and beef tallow + coconut oil $50+$ $50 \%$. The time needed for all tests to be truly constant is 200 minutes.

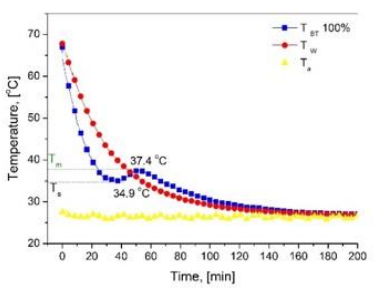

(a)

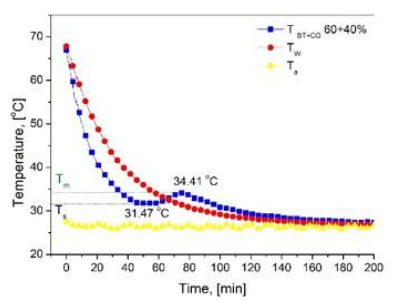

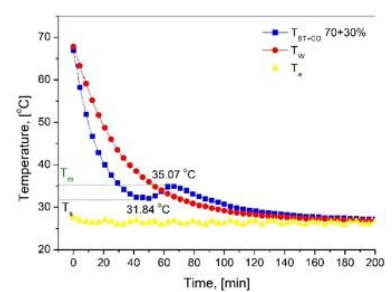

(b)

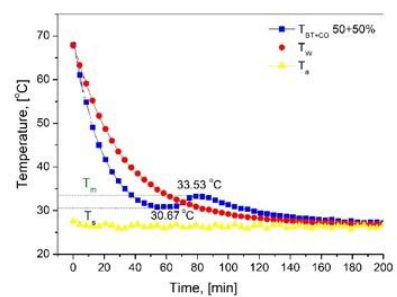

Fig. 2. Temperature profile at beef tallow/coconut oil bio PCM samples; (a) $100 \%$ beef tallow, (b) beef tallow + coconut oil $70+30 \%$, (c) beef tallow + coconut oil $60+40 \%$, and (d) beef tallow + coconut oil $50+50 \%$.

It is seen that the PCM sample and reference sample in the test tube during the cooling/freezing process experienced a decrease in temperature. For bio PCM samples undergoing supercooling process during the solidification process, while for water (reference) there is no supercooling. Based on the graph obtained supercooling temperature, melting temperature, and supercooling degree. The amount of supercooling temperature, melting temperature for each bio PCM sample $100 \%, 70+30 \%$, and $50+50 \%$ are 34.9 , $31.84,31.47,30.67{ }^{\circ} \mathrm{C}$ and $37.4,35.07,34.41,33.53{ }^{\circ} \mathrm{C}$. From these data it can be seen that the effect of adding coconut oil to beef tallow results in a decrease in supercooling temperature and melting temperature Whereas the degree of supercooling for each bio PCM sample is $100 \%, 70+30 \%$ and $50+50 \%$ are $2.5,3.23,2.94$, and 2.86 ${ }^{\circ} \mathrm{C}$ as shown in Figure 3.

After obtaining supercooling temperature, melting temperature and supercooling level on the bio PCM sample then the calculation of specific heat (solid and liquid), and latent heat was carried out. The amount of specific heat (solid and liquid), and latent heat from the Bio PCM sample is obtained by using equations 1-3. The results are summarized in Table 1.

Based on Figure 3, it can be seen that melting temperature of beef tallow/coconut oil obtained is between $33.53-37.4$ ${ }^{\circ} \mathrm{C}$. The magnitude of this melting temperature can be recommended for applications on building walls where PCM used for applications on building walls has a range temperature $0-65^{\circ} \mathrm{C}$ [16], [17]. In addition, based on the amount of melting temperature obtained, it can be seen that there is an effect of decreasing the melting temperature on beef tallow due to the addition of coconut oil from 37.4 to $33.54{ }^{\circ} \mathrm{C}$. The decrease in melting temperature is very good if applied to the walls of the building because the load for the cooling system is getting smaller so that it can increase the efficiency of electricity consumption.

While the data obtained from Table 1 shows that the 
effect of adding coconut oil to beef tallow caused a latent heat reduction from 101.05 to $72.32 \mathrm{~kJ} / \mathrm{kg}$. Another effect of this latent heat reduction causes the need for a lot of material when used for applications on the walls of the building when compared to without the addition of coconut oil to beef tallow.

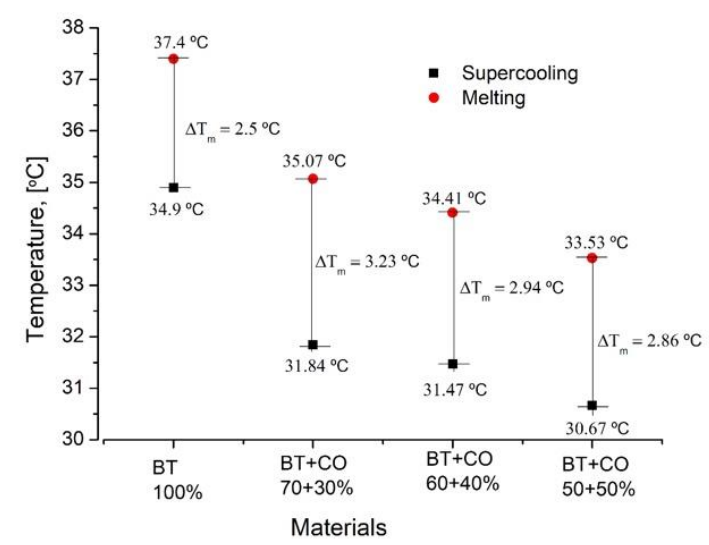

Fig. 3. Supercooling degree of bio PCM beef tallow/coconut oil

TABLE I: THERMAL PROPERTIES OF BEEF TALLOW/COCONUT OIL BIO PCM MATERIAL BASED ON T-HISTORY TESTING

\begin{tabular}{|c|c|c|c|c|}
\hline Materials & $\begin{array}{l}\text { Composition, } \\
{[\%]}\end{array}$ & $\begin{array}{l}\mathrm{C}_{\mathrm{p}, \mathrm{l}}, \\
{\left[\mathrm{kJ} / \mathrm{kg} .{ }^{\circ} \mathrm{C}\right]}\end{array}$ & $\begin{array}{l}\mathrm{C}_{\mathrm{p}, \mathrm{s}} \\
{\left[\mathrm{kJ} / \mathrm{kg} .{ }^{\circ} \mathrm{C}\right]}\end{array}$ & $\begin{array}{l}\mathrm{H}_{\mathrm{m}}, \\
{[\mathrm{kJ} / \mathrm{kg}]}\end{array}$ \\
\hline BT & 100 & 2.96 & 2.59 & 101.05 \\
\hline $\mathrm{BT}+\mathrm{CO}$ & $70+30$ & 2.8 & 2.48 & 85.48 \\
\hline $\mathrm{BT}+\mathrm{CO}$ & $60+40$ & 2.5 & 2.47 & 81.18 \\
\hline $\mathrm{BT}+\mathrm{CO}$ & $50+50$ & 2.25 & 2.19 & 72.32 \\
\hline
\end{tabular}

\section{CONCLUSION}

Testing the thermal properties of bio PCM beef tallow/coconut oil using the T-History method for applications on building walls has been successfully carried out, and data on desired thermal properties have been obtained. The conclusion is that the amount of latent heat, specific heat, and melting temperature for beef tallow without coconut oil are $101.05 \mathrm{~kJ} / \mathrm{kg}, 2.25 \mathrm{~kJ} / \mathrm{kg}^{\circ} \mathrm{C}$ and 37.4 ${ }^{\circ} \mathrm{C}$ respectively. While latent heat, specific heat, and melting temperature for beef tallow with coconut oil are 72.32-85.48 $\mathrm{kJ} / \mathrm{kg}, 2.19-2.8 \mathrm{~kJ} / \mathrm{kg}^{\circ} \mathrm{C}$, and $33.53-35.07{ }^{\circ} \mathrm{C}$ respectively. The effect of adding coconut oil to beef tallow causes a decrease in latent heat. However, the effect of the decline can still be used on building wall applications.

\section{REFERENCES}

[1] İ. Yüksek, "The Evaluation of Building Materials in Terms of Energy Efficiency," Period. Polytech. Civ. Eng., vol. 59, no. 1, pp. 45-58, Feb. 2015.

[2] S. Al Hallaj and J. R. Selman, "A Novel Thermal Management System for Electric Vehicle Batteries Using Phase-Change Material," J. Electrochem. Soc., vol. 147, no. 9, pp. 3231-3236, 2000.

[3] D. Zhou, C. Y. Zhao, and Y. Tian, "Review on thermal energy storage with phase change materials (PCMs) in building applications," Appl. Energy, vol. 92, pp. 593-605, Apr. 2012.

[4] N. Putra, M. Amin, E. A. Kosasih, R. A. Luanto, and N. A. Abdullah, "Characterization of the thermal stability of RT $22 \mathrm{HC}$ graphene using a thermal cycle method based on thermoelectric methods," Appl. Therm. Eng., vol. 124, pp. 62-70, 2017.

[5] Y. Lin, Y. Jia, G. Alva, and G. Fang, "Review on thermal conductivity enhancement, thermal properties and applications of phase change materials in thermal energy storage," Renew. Sustain Energy Rev., vol. 82, pp. 2730-2742, Feb. 2018.

[6] R. Thaib, S. Rizal, M. Riza, T. M. I. Mahlia, and T. A. Rizal, "Beeswax as phase change material to improve solar panel's performance," IOP Conf. Ser. Mater. Sci. Eng., vol. 308, no. 1, p. 012024, Feb. 2018.

[7] N. Putra, E. Prawiro, and M. Amin, "Thermal properties of beeswax/CuO nano phase-change material used for thermal energy storage," Int. J. Technol., vol. 7, no. 2, 2016.

[8] S. Wi, J. Seo, S.-G. Jeong, S. J. Chang, Y. Kang, and S. Kim, "Thermal properties of shape-stabilized phase change materials using fatty acid ester and exfoliated graphite nanoplatelets for saving energy in buildings," Sol. Energy Mater. Sol. Cells, vol. 143, pp. 168-173, Dec. 2015

[9] O. Dahimi et al., "Multivariate statistical analysis treatment of DSC thermal properties for animal fat adulteration," Food Chem., vol. 158, pp. 132-138, Sep. 2014.

[10] C. Rathgeber, L. Miró, L. F. Cabeza, and S. Hiebler, "Measurement of enthalpy curves of phase change materials via DSC and T-History: When are both methods needed to estimate the behaviour of the bulk material in applications?," Thermochim. Acta, vol. 596, pp. 79-88, Nov. 2014.

[11] I. Sarbu, C. Sebarchievici, I. Sarbu, and C. Sebarchievici, "A Comprehensive Review of Thermal Energy Storage," Sustainability, vol. 10, no. 2, p. 191, Jan. 2018.

[12] R. Thaib, M. Riza, M. Amin, and S. Rizal, "Application T-History method on measurement of thermal properties of phase change material as latent heat storage in solar water heating system," IOP Conf. Ser. Mater. Sci. Eng., vol. 434, no. 1, p. 012171, Dec. 2018.

[13] N. Şahan and H. Paksoy, "Determining influences of SiO2 encapsulation on thermal energy storage properties of different phase change materials," Sol. Energy Mater. Sol. Cells, vol. 159, pp. 1-7, Jan. 2017.

[14] A. Solé, L. Miró, C. Barreneche, I. Martorell, and L. F. Cabeza "Review of the T-history method to determine thermophysical properties of phase change materials (PCM)," Renew. Sustain. Energy Rev., vol. 26, pp. 425-436, Oct. 2013.

[15] Z. Yinping, J. Yi, and J. Yi, "A simple method, the -history method, of determining the heat of fusion, specific heat and thermal conductivity of phase-change materials," Meas. Sci. Technol., vol. 10, no. 3, pp. 201-205, Mar. 1999.

[16] F. Agyenim, N. Hewitt, P. Eames, and M. Smyth, "A review of materials, heat transfer and phase change problem formulation for latent heat thermal energy storage systems (LHTESS)," Renew. Sustain. Energy Rev., vol. 14, no. 2, pp. 615-628, 2010.

[17] T. Kousksou, P. Bruel, A. Jamil, T. El Rhafiki, and Y. Zeraouli, "Energy storage: Applications and challenges," Sol. Energy Mater. Sol. Cells, vol. 120, pp. 59-80, 2014. 